INTERNATIONAL JOURNAL OF

ECO-CULTURAL TOURISM, HOSPITALITY PLANNING

AND DEVELOPMENT

THE IMPACT OF ANCIENT EGYPTIAN TOURISM ARTS IN THE DEVELOPMENT OF TEXTILE PRINTING

Samer Ahmed Sayed ABDEL HAFEZ ${ }^{1}$, Bilal Ahmed Ibrahim MOQLED ${ }^{1}$, Iman Abdullah MOHAMED ${ }^{2, *}$

${ }^{1}$ Textile Printing Department, Technical Education College, Helwan University, Egypt

${ }^{2}$ Textile Printing Department, Faculty of Specific Education, Assiut University, Egypt

\begin{abstract}
Egypt and the secrets of beauty (the mother of the world) is an oasis of security and safety. May God love Egypt without other countries of the world with an ancient historical heritage that makes it one of the first countries on the tourist map, and from here the importance of Egypt among the countries of the world appears due to its distinguished long history and its tourist attractions The student noticed that the Egyptian artist was affected by the existing tourist and historical monuments, and they were sources of inspiration for his subjects and elements to be used in his artistic works, and among the topics of inspiration that God loved Egypt without others, and from here the importance of Egypt appears among the countries of the world because of its distinguished ancient history and what it enjoys. One of the tourist attractions, "Egypt also includes many types of tourist attractions, which makes it enjoy a competitive advantage in tourism in general and a holistic advantage that is not competitive in Pharaonic archaeological tourism in particular." From this he concludes that ancient Egypt is the cradle of human civilization, the cradle of wisdom, and the fountain of arts and science, and it will always be An eternal mystery, and it is rightly stated by (Herodotus), the ancient Greek historian (that it is the cradle of wonders). From the above, the intellectual starting point for research in an attempt to identify the arts of ancient Egyptian tourism civilizations, and their impact on the development of printing.

Keywords

\title{
Introduction
}

The research problem can be determined in the following question: What is the possibility of identifying the impact of the ancient Egyptian tourism arts in the study:

Once Egypt, in several different eras, resulted in the greatest civilizations, and when talking about these ancient civilizations, we must address what they contain of arts, as the arts were the basis of these civilizations.

Egyptian art in the Pharaonic civilization: The Pharaonic civilization flourished in Egypt from an early age, and that civilization lasted for thousands of years, and once in several eras, the first of which: - The ancient era found that the works of art belonging to this period are few compared to the works of the ancient and modern state, and these works were found. In the royal tombs and early temples dating back to the ancient era, "the statues of the king (KhaaSakhem) were found in the ruins of one of the early temples, as well as the foundations of the statues of the king $(\mathrm{Q}-\mathrm{A})$ in a temple attached to his tomb that was built of mud bricks.

* Corresponding author: specedu@aun.edu.eg 
The effects of that period are the slate of King Narmer, the slate of King Narmer is considered one of the most important features of the artistic development that took place in the dynastic era. This development is represented in the "thinness and thinness of lines, and in the realization of the value of modification and abstraction in the representation of organic forms in accordance with the requirements of the design of the ancient Egyptian civilization arts In the development of textile printing in the old country, architecture and sculpture, in particular, reached a great affair in the old country that it did not reach in the following eras. "Artworks in the Old Kingdom era were characterized by calmness, good coordination, orderliness and freedom. He adhered to the principles and decorated the tombs and the grandiose terraces in the Old Kingdom with many works of inscriptions, and among the most important statues of the Old Kingdom is the statue of King Khafre of the blue diorite stone, as it is considered an exquisite formative expression that has incorporated both the king and the god into one essence. "The statue is extremely united and judged by the values of rhythm. The proportion and equilibrium are given to each other in a tight mathematical law that helped in its strength and clarity. The choice of the solid diorite material. The statue is characterized by idealism and attractiveness. Its lines are characterized by strength, flexibility and vitality, and they reveal a delicate sense and knowledge of the origins of anatomy, as appeared in the era of the old country the manufacture of metal statues, and among these statues the king statue Baby I, who was found in the HierranksConpoles and is characterized by vivacity of expression, beauty of the face and sparkle of the studded eyes, as for the scenes of the inscriptions in the Old Kingdom, they represent scenes of daily life and its activities such as fishing, shipbuilding, baskets, weaving and wine, "as it increased in the second half of the Fifth Dynasty the rooms that It is contained in the part built above the ground of the cemetery, which led to the many views that decorate its walls, including the views of the broader The agricultural and various industries, and among the most famous tombs dating back to the Old Kingdom are the tombs of T and Ptahhotep in the Fifth Dynasty, and the tombs of Mari Roca and Kagmini in the Sixth Dynasty, and they are all located in the Saqqara region

\section{- The Middle State}

In the Middle Kingdom era, some local art workshops appeared in Thebes in the south and in Memphis in the north. The northern workshops were characterized by their tenderness, softness, and clear human features, despite some embellishment, but unlike them, the artistic factories in Thebes clearly tended to highlight manifestations of strength and physical aggression. In addition to a bit of strict realism at times, and attributed to the artistic workshops in Thebes, the statue of King Mentuhotep II, which was found in the funerary temple of the 
king in the Deir el-Bahari, and the statue was carved from sandstone, and during the Middle Kingdom era increased models made of limestone, and models made of wood Painted with colored plaster, these models were characterized by vitality, freedom and spontaneity in shaping away from strict artistic rules and restrictions, and the color wall painting was more common than the bas-reliefs in the Middle Kingdom era, and among the most beautiful reliefs in that era was the coffin of Queen Kawit, wife of King Mentuhotep the First, who was found On him in the Deir el-Bahari, on the first face of the coffin, one of the servants appears while milking the cow, tied in its legs to its young child. The other face of the coffin, where the servant presents the milk that he milks to the Lady Kawit, who appeared sitting eating a cup of drink while the maid styled her wig hair, and the Bani Hassan tombs are considered one of the most important tombs of the Middle Kingdom, which contain colorful wall paintings and their subjects deal with scenes from life Daily activities such as farming, herding and fishing, in addition to the spread of scenes of acrobatic games, dancing, wrestling, and military preparation, according to the sequence of a group of unique shots.

\section{- The modern state}

Architecture and art reached its golden age in the era of the modern state, and the greatest temples were built in Thebes, such as the Karnak Temple Complex, Luxor Temple and Hatshepsut, and the number of tombs in Thebes, which replaced the pyramids as a home for the deceased and a point of entry into the other life, and then increased the areas of decorated walls, which helped to create The spread and development of the art of color photography in cemeteries, and the inscriptions in the temples, "the luxury that occurred in Egypt during the era of the conquests in the modern state also affected the art of sculpting statues, so the art of sculpture acquired freshness, attractive elegance, flexibility in lines, in addition to the characteristics of strength and stiffness that distinguished it in the era of The ancient and middle states, and tomorrow, the style of sculpture with its beautiful plastic molds, the impact of the ancient Egyptian tourism civilizations in the development of textile printing

His head is crowned by the blue crown, with his right hand centered above his chest, holding the scepter, and the left hand clenched above his knee, and on both sides of his legs appeared his wife Nefertari in a small size and his son (Amun Free Scribble F). The sculpture of the statue is characterized by the beauty of lines and proportions and reflects the splendor and artistic completeness. Wall photography is its golden age in the era of the modern state as a result of the increase in the number of tombs in Thebes and the need for speedy implementation and the difficulty of carving the rock wall, and among the most beautiful examples of color photography in the era of the modern state, the mural pictures in the tomb of Queen Nefertari 
in the Valley of the Queens, they are distinguished by the broadcast of their colors and attractiveness of drawing His paper, which shows the queen with graceful texture and charming features.Egyptian art in the Coptic era: We find the Coptic artist in the Christian era relied on the subject element as one of the basic features to highlight his art, which was closely related to religion, as was the case with ancient Egyptian art, and as there is a real difficulty in identifying The identity of the artistic movement in Egypt during the Christian era, and perhaps the difficulty here falls under the concept of mixing occurring in Egyptian society by the influence of the Greek and Roman presence in Egypt, and this resulted in responses

Various and complex artistic and cultural actions that expressed the popular concept in the Egyptian society in that era. Art came as a complement to the historical variables, in keeping with the new religious vision and expressing the culture of a people. Coptic art used to represent the entity and personality of the Egyptians. "It was found that those in charge of building the edifice Coptic architects use ancient architectural models, starting with the use of small temples and then major ones and modifying the spacious places inside them with environmental architectural elements and materials, such as building rooms and walls with mud bricks on them with a thin layer of mortar, as a result of the ancient Egyptian tourism arts in the development of white textile printing, and with the emergence of wall photography as one of the art Photography, in its early beginnings, was not a separate or stand-alone art, but was completely linked to architecture as one of its artistic elements, and became an integral part of the architectural design, then the art of wall photography moved

To another, more advanced stage, "with the mid-thousandth of a quarter $\mathrm{BC}$, where the Egyptians knew the industrial technique of this art and used it on mud brick walls covered with clay mortar, and we reach this with the oldest and first technique known to the art of wall photography. Coptic textiles are considered one of the most archaeological relics." The rest and spread in most of the Egyptian museums, and if the art of sculpture and photography contributed to the formation of the features of Coptic art in general, then the art of textile decoration and the manufacture of weaving has played the largest role in the spread and fixation of the strings of Coptic art in its different stages. "Weaving is an art that has its distinct artistic and industrial characteristics that were practiced by the Egyptians. The ancient people since the early ages, then it developed as a local industry since the Greco-Roman period in Egypt, so that the Greek and Roman historians praised those industries in Egypt and the superiority of the Egyptians in it, which confirms that it is a hereditary industry and an entrenched in the Egyptian society. 


\section{- The Islamic era:}

After their conquest of Egypt, the Arabs were able to blend in the Egyptian people, which had the greatest impact on overcoming the Islamic culture and the Islamic religion. Islamic arts have a character in their formation represented in the austerity of representation of living creatures, austerity, interest in decoration and alienation of the impact of the ancient Egyptian tourism civilizations in the development of textile printing from The emptiness, and we find that the Islamic tendency through monotheism has a great role in the first place in faith, so the arts in this regard were affected by the deletion of everything related to human or animal drawing or sculpting their statues, because the pictures and statues point to the idols from which monotheism is feared. We find that the Persians and Egypt during the Fatimid period "tolerated some tolerance in painting and sculpture until you saw in the Fatimid palaces scenes of dancing, hunting and deer, and colored wall paintings dating back to the Fatimid era were found in Egypt and Al-Maqrizi mentioned the existence of a school of Islamic colored wall paintings that flourished in Egypt in the era The Fatimid, "and he mentioned that the Iraqi photographers contended with the Egyptians in drawing wall pictures in which they showed skill in manipulating the effect of colors. The existence of this school is supported by wall pictures found. On it in a bathroom in the Abu Al Saud side in Old Cairo, Islamic art has gone in three directions

Contrasting geometric motifs from arcs and lines ornaments that originate in drawing an animal or plant ornament using Arabic calligraphy and Islamic arts in general are the arts of the mind, lacking insight, vision and imagination, and it tends to perfect the workmanship while neglecting the purpose of the art, so its position was not Great among Muslims, so that we rarely find the name of the manufacturer written next to an inscription or even a building, and Islamic arts followed different styles, which are: - The impact of the ancient Egyptian tourism arts on the development of textile printing:

- Art of the book

- Art of binding

- Architecture art

- art of photography

Hence, we find that the ancient civilizations that Egypt once had a great role in the tourism industry, with the arts rich in these civilizations that had the greatest impact on the presence of tourist attractions in addition to the historical legacy of those civilizations, "Egypt is a mythical civilizational treasure whose secrets are revealed only to those who know the meaning of 
beauty. It is the oasis of the world and the heart of the world whose voice infiltrates your heart, it is truly beautiful that philosophers and thinkers from all the world adore and in all ages, beauty envelops everything in Egypt, starting from the eternal Nile page, and passing through its great effects, it is magic and greatness, it is the repository of civilization and the Museum of History that It is full of life and vitality, there is no inch in it that does not tell a story or myth, and leaves a mystery that drives those who visit it to nostalgia for it, because it is a witness to the world's civilizations and in their lands are treasures that reveal every day a letter of the alphabet of civilization, so whoever visits Egypt

It falls into the ropes of its magic, and it becomes secrets for its adoration, and whoever drinks from the Nile water must return to it no matter the distances, "and the ancient civilization of Egypt is rich in various innovations and has been characterized by renewal, originality, and continuity for three thousand years, and the Nile and the flood taught humans stability, agriculture, arithmetic, engineering and astronomy, and that We talked about the architecture arts in ancient Egypt, as evidence of its innovations from pyramids and temples still remains, and we dealt with plastic arts, industries and crafts, so the museums of the world abound with their creativity, and no matter how long the conversation lasts, we cannot fulfill its due. The impact of the ancient Egyptian tourism arts in the development of textile printing and on this, ancient and modern Egypt is rich. With many tourist attractions that are characterized by renewal, originality and continuity from ancient times until now. The most important monuments and archaeological tourist areas in Egypt: What is written about Egypt is much more than what was written about other countries, so there is no doubt that there is no such thing in another country in the country Its effects are on its feet, its splendor, its abundance, and the beauty of its art, and perhaps it is the only country in the world in which one can trace the step of the history of a people during fifty centuries From time, in light of the relics, most of which are still standing today, and through writings and inscriptions on stones, temples, obelisks, papyrus papers and the like, which kept the safe land of Egypt, the archaeological regions and monuments in the Egyptian cities in the north, south, east and west, and the traces of Pharaonic, Islamic, Roman and Coptic monuments they contain It is taken from the book Archaeological and Tourist Attractions in Egypt written by Angham Abdel Moneim and Hoda Abdel Moneim. The pyramids are witnesses to the tombs of the great kings of the Pharaohs. She said about her, "Amelia Edwards is impossible to tire of seeing the pyramids, and it is the subject of the visitor's interest in the greatest buildings in the world. The Sphinx, about which Harriet Martineau said, is a sacred symbol of the union of the strongest physical strength with the greatest mental strength on earth, Abu Al-Hol is the owner of the desert and the guardian 
of the Kingdom of the Immortals. The Egyptian Museum is one of the most important museums in Egypt, but in the world, as it is the Museum of Ancient Egyptians. The museum is the best reference to ancient Egyptian art, as it collects everything that is important to history and art in ancient Egypt. Fortress of Babylon

The greatest of them, and it was called the suspension because it is based on the ruins of the walls of two large towers of the Roman fortress. The Blessed Virgin tree: This tree is found in the Matareya area and is one of the most important Christian shrines in Egypt. Its age is more than two thousand years. Despite this long life, it isEvergreen.

\section{- Old Cairo}

The castle was established during the reign of Salah al-Din al-Ayyubi to be a fortress to protect Cairo on a hill of Mokattam Mountain in the twelfth century, and there are several buildings in the castle, including the Military Museum and the Vehicle Museum, and the castle is not only an archaeological area but an ancient, ancient neighborhood. The Muhammad Ali Mosque was also called the Castle Mosque because it was built inside the castle or the Alabaster Mosque to clad the walls from inside and outside, and it is a type of Egyptian stones found in Upper Egypt, and the mosque is in the Ottoman style and it is similar to the Sultan Ahmed Mosque in Istanbul called "the Blue Mosque". Al-Azhar Mosque Al-Azhar Mosque is considered as the material and spiritual center of medieval Cairo. The Al-Azhar Mosque was and still is a spiritual ray of the entire Islamic world, established by Jawhar Al-Saqli, and it is considered the oldest Islamic university in the world, and it is one of the most important Fatimid monuments. The Islamic Museum The Museum of Islamic Art, which is located in Bab al-Khalq Square in Cairo, is considered one of the largest and greatest museums in the world, which includes artistic treasures that were created in the shadow of Islamic civilization. The impact of the ancient Egyptian tourism civilizations in the development of textile printing. The Manial Palace built this palace by Prince Muhammad Ali In the middle of a garden containing rare trees that he brought from different parts of the world and the style in which this palace was built is considered a mixture of Turkish, Arab and Persian architecture

\section{- Aswan Governorate}

The city of Aswan enjoys the warm sunshine of Aswan, located on the southern borders of Egypt. It has several islands such as Suhail Island, Botanical Island, and Philae Island, and the city of Nubia also has several temples, including the Kalabsha Temple and Abu Simbel Temple, and there is the Aswan Museum, which contains a set of antiquities, and from the modern antiquities of the Aswan Reservoir and the High Dam, and tourist countries are 
interested in developing and improving their products to suit the renewed requirements For the visitor in a way that achieves sustainability and preserves its cultural and historical heritage, the researcher has noted that tourism in Egypt is one of the sources of inspiration that presents itself to the artist, which shows that "Egypt includes many types of tourist attractions, which makes it enjoy a competitive advantage in tourism in general and a total advantage not Competition is accepted in the Pharaonic archaeological tourism in particular, so it was necessary to address the historical side of the Egyptian civilization, which is considered the tourism legacy of Egypt, hence the Egyptian civilization and tourist attractions are among the first sources of inspiration for the researcher, as they are a fertile source to benefit from in the development of printing

\section{- Printing arts:}

The art of printing is one of the arts that is closely related to man and has a great and tangible impact on his life, so we find that printing is present in many matters of daily life since many centuries ago and the last half of the twentieth century witnessed new printing techniques in many SadiqRiad and Muhammad al-Zanfali: The Egyptian tourist show and the range Attracting tourism demand for people with special needs "The impact of the ancient Egyptian tourism arts in the development of textile printing. Artistic works, whether in the printing of furnishings or printed paintings, this development included methods and modern technological media for preparing those works of art and mixing ancient and modern techniques in a single artwork.

And the art of printing color on fabrics appeared thousands of years ago, directly after making clothes. The primitive man decorated his clothes by printing them, and this is confirmed by some pictures painted on the walls of some Egyptian tombs that depict shapes of printed clothes, so we find "pieces of real textiles printed found near Thebes in Egypt from Around $1011 \mathrm{BC}$, the oldest textiles were found in Europe, dating back to about $011 \mathrm{AD}$, and in America examples of printed fabrics were found in the traces of the Indian civilization Inca))

\section{History of the origins of the printing arts:}

During the search for the origins and history of the printing arts, he found that "historians are not guided to a specific date or a fixed place. When it is possible to know the outside and implementation of primitive decorative units and elements on woven fabrics, however, they have been known from a long time immemorial, and the research is the father of the foundations unanimously. The East has primacy over this industry, especially in Egypt, India, and China. "(2) In primitive times, man used to practice this art in a completely innate manner." By revealing and scientific analysis of this art, it was found that the primitive man used special 
types of glue mixed with the blood of the animals he hunted and then He uses the hand of the artifacts of the ancient Egyptian tourism civilizations in the development of textile printing in a furnishing effect of colors after dipping them in this color dough on the walls of caves and it was also found that he used some colors with natural oxides present in the surrounding environment, and there is no doubt that such drawings that were On the walls of those caves they had an innate artistic beauty, whether in the unit itself or in its innate repetition, and some scholars and historians believe that the art of printing textiles is one of the arts that appeared by chance of existence. Tree leaves with water and then pressed over the cloth, leaving a trace of the compact plant shape, and they see that this accidental or intended process has drawn attention to produce some designs and shapes intentionally and controlledly on the fabrics. Modern discoveries in the pyramids and the excavations of the ancient Egyptians' tombs confirmed their money from an ancient message in the prosperity of this industry. For more than a thousand years BC, the corpses of their dead were surrounded by linen textiles printed in bright colors that did not lose their beauty despite the passage of this long time, and one historian mentioned that they were on a complete circle using various color fixatives and were often composed of an extract of some plant materials. Civilization A, this art had disappeared on the banks of the Nile in the era of the ancient Egyptians, "dating back to the pre-dynastic era, and the city of Akhmim was also important centers for this industry in that."

The time when traces of printed fabrics were found, and wonderful relics were also found in the tomb of King Tutankhamun, which consisted of mummification coils, clothes, curtains and blankets of the impact of the ancient Egyptian tourism arts in the development of textile printing by the deacon, all of linen, despite the convergence of the sayings of historians to determine the primacy of peoples By using the means of printing on fabrics in color, their consensus is that the East is credited with inventing this art and its origin since the earliest eras of history and from it to all other nations. "So I found in India traces of printed cotton fabrics dating back to the year two thousand and five hundred B.C. History recorded the great skill of the Indians in The fabrics were printed with wooden blocks, and their models were engraved in bright colors, very beautiful and accurate, which impressed them

And the appreciation of the women in the time of the Roman Empire, and they referred to it in rosy solutions due to the abundance of flower drawings in it.

\section{Printing arts in Egypt:}

Egypt is considered one of the most ancient countries in which the arts flourish, and through researching Egyptian history, it was found that Egyptian fabrics became famous in the era of Islam and historians wrote about them everywhere and was softly striking their fabric, as it was 
said that a garment of a length of yards can be pulled to the accuracy of its weaving from an opening The finger ring, and the industry in Egypt for weaving and printing it was an extension of the renaissance of the ancient Egyptians, but the Islamic era was concerned with this industry in particular, and the Umayyad and Abbasid states in Egypt were entrusted with building a role for the model throughout the Egyptian country, in addition to the presence of some of them in the homes of the caliphs to weave luxurious, excellent clothes for the caliphs. They themselves or the closest relatives of the caliphs who hold official positions and these clothes were considered as decorations of honor for individuals to be proud of, and so it was

In Egypt, there are private-style houses and public-style houses, and this was mentioned in the plans that were on the fabrics, each of which shows the house of the style that it produced, and the manufacture of linen and silk fabrics reached a great degree in the Abbasid and Toulouse era and was exported to Syria and Iraq, and then the industry advanced in Syria after that. So that there is no difference between their textiles and those of Egypt, but rather specialized in (brocade) cloth. It is well known that Egypt and Syria in most of the eras of Islam were one country. As for the style houses that had a great reputation in the city of "Tennis, an Egyptian island located in Port Said Governorate in Egypt." Southwest of Port Said, in Lake Manzala, Tennis was an Egyptian floral city in Islamic times and it was famous for its textile industry in Egypt, and it was famous for its five thousand and specialized in certain types of weaving, such as very thin turbans or the badana, which was the clothing of individuals and Boukalmon, which is a corrugated fabric that changes in color In light, he used to wear saddles and covers for royal lodges, and due to the ingenuity of the tennis people in the textile industries, they were annually entrusted with manufacturing the covering of the Kaaba. Supervising Suad Maher: Islamic Textile - The Central Organ Cairo University Library - 1227 AD. Damascene brocade fabric is considered the most famous and luxurious type of fabrics and textiles in the world. The cloth is made of gold, silver and natural silk threads. The city of Damascus in Syria has been unique to it since ancient times and has craftsmanship and industry of specialists and famous.

\section{Recommendations:}

1. The importance of arts in ancient civilizations.

2. This research recommends interest in tourism.

3. Civil society must have its clear mark in preserving the tourism potential.

4. The printing arts are a fertile field for expressing the cultural heritage.

5. The impact of the ancient Egyptian tourism arts on the development of textile printing. 


\section{References:}

1. Hamdarshanov, Babasid: design in plastic art - Cairo, the world of the book.

2. Amelia Ann Blanford-Edwardes, novelist, journalist, case, and Egyptian-English scholar.

3. Angham Abdel-Moneim and Hoda Abdel-Moneim: "Archaeological Monuments and Tourism in Egypt", Darnahda Al Sharq, First Edition, 2112 AD.

4. Gyarshih: "The Comprehensive Encyclopedia of Pharaonic Civilization", translated by Fatima Abdullah Mahmoud, The Supreme Council of Culture, Cairo, 2110AD, p. 243.

5. Hassan Rashid Abu Abdel Raouf Fansar: Textile Dyeing - Dar Al-Zeiny - Cairo 1441 A.D.

6. Salam Hammousa: "History of the Arts and the Months of Pictures", Publishing House, Hindawi Foundation for Education and Culture, 2112 AD, p. 24

7. Cyril Aldred: “Ancient Egyptian Art”, Cairo, Supreme Council of Antiquities, First Edition, 1441 CE, p. 06.

8. Saad Shehab Muhammed Kamil: Textile Chemistry and Dyeing theoretically and practically - Cairo - Dar Al Nahda - 1401 AD.

9. Samira Al-Sharif: Technical Treatments for Pharaonic Stencils and Personal Printings Conference on Arts and Environment - Faculty of Art Education - Helwan University 1444 AD.

10. Samira Al-Sharif: The technical capabilities of the light and the objectives of basic education - Master's thesis - Faculty of Art Education, Helwan University - 1416 AD.

11. Souad Maher: The Islamic Textile - The Central Organ of Cairo University Library - 1441 A.D. The art of ancient Egyptian tourism civilizations in the development of textile printing

12. Sadiqriyyadh and Muhammad Al-Zanfali: The Egyptian Tourism Offer that Attracts Him to the Political Demand with Special Needs, Al-Research Magazine, United Cairo for Printing, Publishing and Distribution, July 2011, p. 36.

13. Izzaki and Muhammad Abd al-Fattah: "Coptic and Byzantine Antiquities," Alexandria, AlHadary Press, 2112 AD, p. 21.

14. Mohsinatieh: "The Immortal Beauty of Ancient Egyptian Art", Cairo Alam Al-Maktab, 2111 AD, p. 11.

15. Muhammad Hamed Mahmoud Rasmi: "Developing the plastic arts capacity of students of the College of Art Education through tasting sculptural works in museums", unpublished master's thesis, Faculty of Art Education, Helwan University, 1410, p. 112.

16. Muhammad Anwar Shukry: "The ancient Egyptian art from our time to the end of the ancient state", The Egyptian General Organization for the Book, 1441AD, p. 122. 
17. Muhammad Salih Ali Buhwarjsourouzian: "The Egyptian Museum”, Supreme Council of Antiquities Press, 1444 AD, p. 4.

18. Mahmoud Abdel-Rahman, the development of treatments for dispersed dyes in the fields of hand printing and dyeing, Doctor's Thesis, Faculty of Art Education, Helwan University 2113 AD, p. 41

19. Claire Alwait: "Art and life in Pharaonic Egypt," previous reference, p. 223.

20. Nemat Ismail Al-Alam: "The Arts of the Middle East in the Islamic Era", Cairo, Dar AlMaarif, 1414 AD, p. 124

21. The brief guide to their Islamic and Coptic antiquities in Cairo, by Publisher.

22. Printing, Library of the Ministry of Education, Kuwait, by Samira Al-Sharif, first edition, year 2111, p. 12

23. http://www.factmonster.com/encyclopedia/history/tennis .html

Received: April 15, 2020

Accepted: June 20, 2020 